\section{Sulfur Deficiency in Poinsettia}

\author{
Mary E. Dale ${ }^{1}$, Ellen T. Paparozzi ${ }^{2}$, and James D. Carr ${ }^{3}$ \\ University of Nebraska-Lincoln, Lincoln, NE 68583
}

Additional index words. Euphorbia pulcherrima, inductively coupled plasma emission spectroscopy, nutrient, nutrition, leaf tissue

Abstract. Cuttings of Euphorbia pulcherrima Willd. ex Klotzsch 'Dark Red Annette Hegg' were grown hydroponically in minus $S$ Hoagland's solution modified to supply $0,1,2,4$, or $8 \mathrm{mg}$ S/liter for 8 weeks. Nutrient solution changes; visual observations, sampling of tissue, and measurement of electrical conductivity and $\mathrm{pH}$ were done every 2 weeks. Deficiency symptoms appeared after 4 weeks of growth in treatments supplying 0 or $1 \mathrm{mg}$ S/liter and occasionally in treatments supplying $2 \mathrm{mg} \mathrm{S} / \mathrm{liter}$. Symptoms included reddening of the petiole and main vein of new leaves followed by yellowing of these leaves. Leaf tissue $S$ levels ranged from 700 to $3600 \mathrm{mg} \mathrm{S} / \mathrm{kg}$ of plant. Deficient levels were identified as $<2200 \mathrm{mg} \mathrm{S} / \mathrm{kg}$ of plant. Suggested critical tissue levels of $\mathrm{S}$ would be 2300 to $3000 \mathrm{mg} \mathrm{S} / \mathrm{kg}$ of plant leaf tissue.

Sulfur is an essential macronutrient for plant growth and development, yet little research has been done to determine critical levels for horticultural crops. Research has been limited previously by difficult, unreliable, and expensive $\mathrm{S}$ detection techniques.

Extensive research has been done on the nutrient requirements of poinsettias resulting in recommended/optimal leaf tissue levels for all the macronutrients except $\mathrm{S}$ (Ecke and Matkin, 1976). Additionally, nutrient deficiency symptoms for $\mathrm{N}$ (which may be confused with $\mathrm{S}$ deficiency in some crops), $\mathrm{P}$, $\mathrm{K}, \mathrm{Ca}, \mathrm{Mg}$, and $\mathrm{B}$, and the effects of added $\mathrm{F}$ and $\mathrm{Na}$ on poinsettias grown in sand culture have been typified (Widmer, 1953). This plethora of information makes poinsettia an ideal crop for $\mathrm{S}$ experiments.

The objectives of this study were to : 1) describe S deficiency symptoms; 2) determine deficient and minimal critical $S$ levels in leaf tissue for poinsettias grown hydroponically.

Phenolic foam in which 'Dark Red Annette Hegg' poinsettia cuttings were rooted was removed and plants were grown hydroponically using minus S Hoagland's solution (Hoagland and Arnon, 1950). Sulfur was added in the form of $\mathrm{Na}_{2} \mathrm{SO}_{4}$ at logarithmic rates from 0 to $64 \mathrm{mg} \mathrm{S} /$ liter. Twice weekly $0.50 \mathrm{mg} \mathrm{Fe} /$ liter (chelated) was added to each pot, All $\mathrm{N}$ was in the nitrate form. Nutrient solutions were changed every 2 weeks to prevent salt accumulation, major $\mathrm{pH}$ changes, and nutrient depletion (Hoagland and Arnon, 1950; Asher et al., 1965; Hewitt, 1966). Additional water was not supplied in the in-

Received for publication 11 Oct. 1988. University of Nebraska Agricultural Research Division Journal Series no. 8764. This research was funded in part by Paul Ecke Poinsettias. Harris Laboratories, Lincoln, Neb., is gratefully acknowledged for ICP analysis of S. The cost of publishing this paper was defrayed in part by the payment of page charges. Under postal regulations, this paper therefore must be hereby marked advertisement solely to indicate this fact.

'Former Graduate Research Assistant.

${ }^{2}$ Associate Professor, Horticulture.

${ }^{3}$ Professor, Chemistry.

${ }^{2}$ Deficiency symptoms occurred in all plants.

'Deficiency symptoms occurred in one or more plants. peroxide (Huang and Schulte. 1985). Sulfur levels in the digested material were determined using inductively coupled plasma emission spectroscopy (ICP).

Experiment 1. Each of four benches was divided into four blocks for a total of 16 blocks. Each block contained all eight $\mathrm{S}$ levels $(0,1,2,4,8,16,32$, and $64 \mathrm{mg} \mathrm{S} /$ liter, with one plant per treatment). To account for an east-west temperature gradient and a suspected north-south light gradient, destructive sampling was done on all treatments in each of four blocks per sampling period. The blocks were arranged in a Latin square to ensure that each point on the gradient was represented at each sampling period. This experiment was used for visual observations and to narrow the range of treatments. Plant material sampled was digested and then $S$ was detected by ion chromatography (IC). Values obtained from this method were unreliable, thus, the plant material from Expt. 2 was analyzed using an ICP.

Experiment 2. A randomized completeblock design with six blocks per each of four benches was used, with five treatments adding Sulogarithmic rates, $0,1,2,4$, and 8 $\mathrm{mg} \mathrm{S} /$ liter. Each of the 24 block-bench combinations had each treatment represented within it for a total of 120 experimental units. Destructive sampling of plants was done by selecting one sample per bench of each treatment every 2 weeks (thus, each block was only partially sampled every 2 weeks).

Statistical analysis was done using SASGLM, and analysis of variance determined for the effect of the level of S supplied on the amounts of $\mathrm{S}$ in the leaf tissue (SAS, 1982). Two regression equations were determined, one for 2 weeks of growth and one for 4,6 , and 8 weeks of growth combined. In addition, since levels of $\mathrm{S}$ supplied were logarithmic, these levels were converted to $\log$, and the appropriate regression equations were determined.

Qualitative results. Yellowing of youngest leaves was first observed in plants supplied with 0 or $1 \mathrm{mg} \mathrm{S} /$ liter and occasionally in treatments supplying $2 \mathrm{mg} \mathrm{S} /$ liter (Fig. 1 and Table 1). The deficiency was evident after 4 to 5 weeks of growth. Yellowing progressed basipetally after fully affecting the young leaves. This yellowing was similar to results reported for some vegetables (Scaife and Turner, 1983) and could be confused with $\mathrm{N}$ deficiency, except that $\mathrm{N}$ deficiency

Table 1. Mean levels of $\mathrm{S}$ in poinsettia leaves and symptom occurrence. All values are the mean of six plants and have been rounded to the nearest 100 . Plant $\mathrm{S}$ content was determined by inductively coupled plasma emission spectroscopy, which is subject to $5 \%$ to $10 \%$ error, and was $5000 \mathrm{mg} \cdot \mathrm{kg}^{-1}$ initially.

\begin{tabular}{|c|c|c|c|c|}
\hline \multirow{3}{*}{$\begin{array}{l}\text { S supplied } \\
\left(\mathrm{mg} \cdot \text { liter }^{-1}\right)\end{array}$} & \multicolumn{4}{|c|}{ Leaf tissue $\mathrm{S}$ levels $\left(\mathrm{mg} \cdot \mathrm{kg}^{-1}\right)$} \\
\hline & \multicolumn{4}{|c|}{ Weeks of growth } \\
\hline & 2 & 4 & 6 & 8 \\
\hline 0 & 2700 & $900^{z}$ & $700^{2}$ & $700^{2}$ \\
\hline 1 & 3300 & $2200^{z}$ & $1700^{x}$ & $1600^{\circ}$ \\
\hline 2 & 3600 & $3000^{y}$ & $3000^{y}$ & $2900^{y}$ \\
\hline 4 & 3300 & 3000 & 3100 & 3000 \\
\hline \multirow[t]{2}{*}{8} & 3200 & 3600 & 3300 & 3500 \\
\hline & \multicolumn{4}{|c|}{$S E \pm 84$} \\
\hline
\end{tabular}




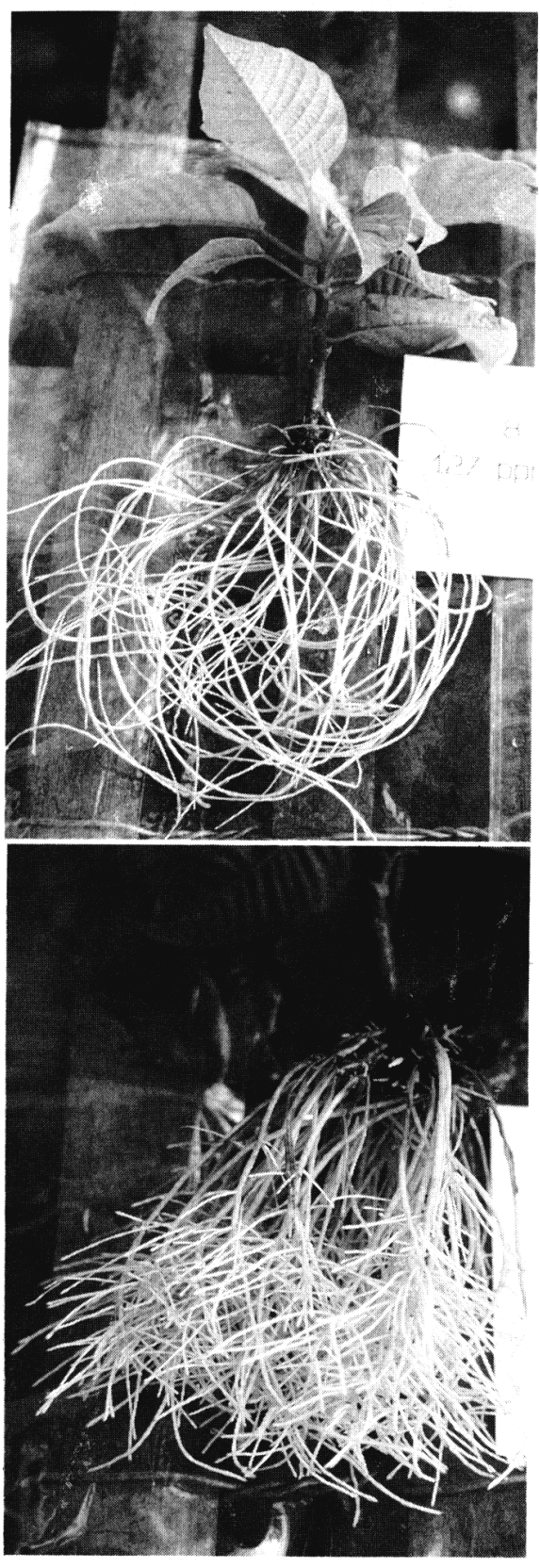

Fig. 1. Poinsettia receiving $0 \mathrm{mg} \mathrm{S} /$ liter showing typical deficiency symptoms (top). Uppermost leaves are yellow and petioles are an intense red. Roots are branchless compared to roots on plants receiving $64 \mathrm{mg}$ S/liter (bottom). Both plants received $127 \mathrm{mg}$ N/liter and were evaluated after 8 weeks of treatment.

in poinsettias has uniform yellowing that begins at the bottom, not the top (Ecke and Matkin, 1976). By 6 weeks of growth, Sdeficient plants were shorter, had slightly deformed growth and reddening of the petioles.

Just prior to the intense yellowing of newly expanded leaves (Fig. 1), the emerging leaves appeared light red, with the veins and petioles on the plant more intensely red than would be expected in 'Dark Red Hegg'. Reddening of the petioles has been reported on poinsettias with $\mathrm{N}$ deficiency (Widmer, 1953). This similarity may suggest a relationship between $\mathrm{N}$ and $\mathrm{S}$. This reddening has also been reported for certain fruit species and is believed to be caused by deficiency in proteins that bind chlorophyll (Bould

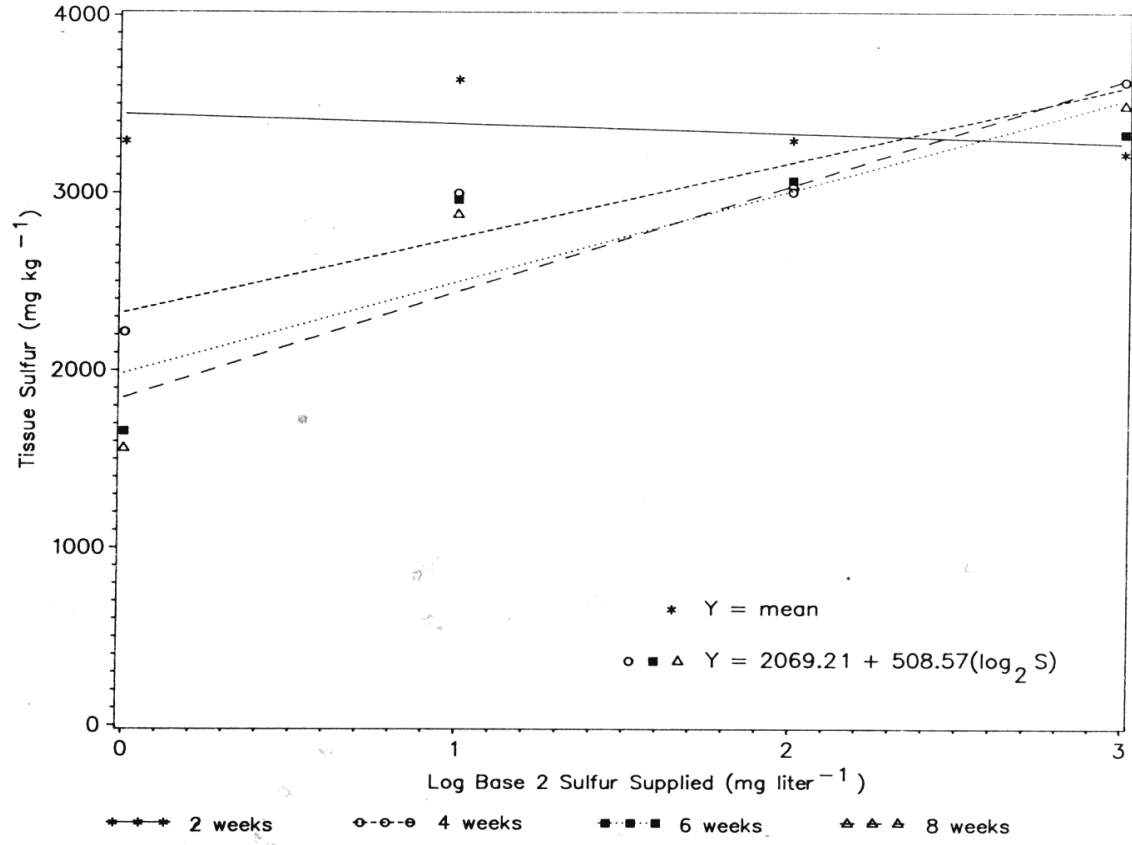

Fig. 2. $\log _{2}$ levels of $\mathrm{S}$ supplied $\left(1,2,4,8 \mathrm{mg} \cdot\right.$ liter $\left.^{-1}\right)$ compared to levels found in expanding young leaves. Each value is a mean of 6 plants. $R^{2}=0.11$ for $\mathrm{Y}=$ mean. $R^{2}=0.85$ for $\mathrm{Y}=2069.21$ $+508.57\left(\log _{2} \mathrm{~S}\right)$.

et al., 1983), as $\mathrm{S}$ is required for chlorophyll formation (Bixby and Beaton, 1970). Therefore, we suggest that $\mathrm{S}$ deficiency merely reveals the anthocyanin already present in the tissues.

The root systems in all treatments were a healthy off-white (Fig. 1). Root quantity appeared proportional to shoot growth, with $\mathrm{S}$ deficient plants being smaller, with correspondingly smaller root systems. Additionally, after 8 weeks of growth, treatments supplying 0 to $2 \mathrm{mg}$ S/liter possessed unbranched roots, while roots for treatments supplying 4 to $64 \mathrm{mg} \mathrm{S}$ /liter were branched. This difference also occurred in other experiments where plants were given varying levels of $\mathrm{N}$ and $\mathrm{S}$ so that the absence of $\mathrm{S}$ was linked to unbranched roots (Dale, 1988).

Quantitative results. Before treatment, plants contained $\approx 5000 \mathrm{mg} \mathrm{S} / \mathrm{kg}$ of plant (determined by X-ray fluorescence). Over 6 weeks, plants receiving 0 or $1 \mathrm{mg}$ S/liter contained decreasing levels of $S$ (Table 1). These plants exhibited S-deficiency symptoms as early as 4 weeks. Plants receiving 4 or $8 \mathrm{mg} \mathrm{S} /$ liter contained a decreased amount of $\mathrm{S}$ at 2 weeks (compared to their initial content), after which levels reached a plateau. These plants did not exhibit any deficiency symptoms. Individual plant values for plants receiving $2 \mathrm{mg}$ S/liter varied in S content and symptomology, thus indicating a dividing point between deficient and sufficient levels.

Comparison of-amounts of S supplied to the plant with plant $\mathrm{S}$ content produced a graphic relationship such that the response at 2 weeks was significantly different from the response at 4, 6, and 8 weeks combined (contrast week 2 vs. weeks $4-8 \times$ sulfur; $P$ $=0.0001$ ) (Fig. 2). Therefore, only two regression equations were determined.
Initially, these two equations indicated quadratic responses at 2 weeks and at 4,6 , and 8 weeks combined, using the actual levels supplied to the plants. However, as the response at 2 weeks $\left(R^{2}=0.20\right)$ gave no confidence that the predicted equation fit the data, levels were plotted using log, scale (Fig. 2). These values showed no discernable relationship between the plant response at 2 weeks and log, S supplied. This lack of plant response after only 2 weeks of treatment was probably due to the high initial S content of the plants. However, when log, S supplied was compared to plant $S$ content at 4,6 , and 8 weeks combined, a linear response occurred. This translates to a positive increase of $\mathrm{S}$ in the plant with increased levels of $\mathrm{S}$ supplied.

Based on these hydroponic experiments, we suggest that $\mathrm{S}$ deficiency will occur in poinsettias when levels of $2200 \mathrm{mg} \mathrm{S} / \mathrm{kg}$ of plant or less are found in young expanding leaves. Sufficient levels in plant tissue are $3100 \mathrm{mg} \mathrm{S} / \mathrm{kg}$ of plant or more (up to toxic levels, not identified in this research). Critical plant tissue levels would range between 2300 to $3000 \mathrm{mg} \mathrm{S} / \mathrm{kg}$ of plant when visual deficiency symptoms may or may not be present.

\section{Literature Cited}

Asher, C.J., P.G. Ozanne, and J.F. Loneragan. 1965. A method for controlling the ionic environment of plant roots. Soil Sci. 100(3):149156.

Bixby, D.W. and J.D. Beaton. 1970. Sulphurcontaining fertilizers properties and applications. The Sulphur Inst. Bul. 17.

Bould, C., E.J. Hewitt, and P. Needham. 1983. Diagnosis of mineral disorders in plants. vol. 1. Principles. Chemical Publ., New York.

Cornell University. 1985. Cornell poinsettia guidelines for 1985. Cornell Univ., Ithaca, N.Y. 
Dale, M.E. 1988. Sulfur nutrition and the effect of the $\mathrm{N}: \mathrm{S}$ ratio on poinsettias. MS Thesis. Univ. of Neb., .Lincoln.

Ecke, P., Jr., and O.A. Matkin. 1976. The poin-, settia guide. Paul Ecke Poinsettias, Encinitas, Calif.

Hewitt, E.J. 1966. Sand and water culture methods used in the study of plant nutrition. 2nd ed.
Cmwlth. Bur. Hort. and Plantation Crops Tech. Bul. 22

Hoagland, D.R. and D.I. Arnon. 1950. The waterculture method for growing plants without soil. Ca. Agr. Expt. Sta. Cir. 347. (rev. ed.)

Huang, C.L. and E.E. Schulte. 1985. Digestion of plant tissues for analysis by ICP emission spectroscopy. Commun. Soil Sci. Plant Anal.
16(6):943-958.

SAS Institute, Inc. 1982. SAS user's guide: Statistics. (1982 ed.). SAS, Gary, N.C.

Scaife, A. and M. Turner. 1983. Diagnosis of mineral disorders in plants. vol. 2. Vegetables. Chemical Publ., New York.

Widmer, R.E. 1953. Nutrient studies with the poinsettia. Proc. Amer. Soc. Hort. Sci. 61:508 514. 